\title{
Examination of the Ascension of the Prophet of Islam in the View of Orientalists
}

\author{
Hassan Rezaee Haftador ${ }^{1}$, Babollah Mohammadee ${ }^{2} \&$ Hossayn Rahnemaee $^{3}$ \\ ${ }^{1}$ Hadith and Qur'anic Sciences Department, University of Tehran, Iran \\ ${ }^{2}$ Hadith and Qur'anic Sciences M.A Student, University of Oloom Qorani, Iran \\ ${ }^{3}$ Theology Ph.D Student, University of Tehran, Iran \\ Correspondence: Hassan Rezaee Haftador, Hadith and Qur'anic Sciences Department, University of Tehran, Iran. \\ E-mail: hrezaii@ut.ac.ir
}

Received: December 15, 2014 Accepted: January 13, 2015 Online Published: February 25, 2015

doi:10.5539/res.v7n3p33

URL: http://dx.doi.org/10.5539/res.v7n3p33

\begin{abstract}
In accordance with Quranic verses, Muslims believe in the nightly journey of the Prophet of Islam from Masjid al-Haram to Masjid Al-Aqsa and his physical ascent into the heavens. This event is named the Ascension (mi'raj). As the Ascension is considered by Muslims to be a miracle of the Prophet of Islam, orientalists have examined the matter. Some orientalists regard the Ascension as essentially true but have different ideas about the manner in which it occurred. For instance, it is believed that the Ascension of the Prophet of Islam transpired in a dream. Others believe that it was not physical but spiritual. This study utilizes logical reasoning and traditional evidence to evaluate the views of orientalists about the Ascension.
\end{abstract}

Keywords: the ascension, the prophet of Islam, Muhammad, orientalists

\section{Introduction}

The Ascension of Muhammad, the Prophet of Islam, is numbered among the controversial subjects about his life. The majority of Muslims believe in the Ascension of the Prophet of Islam on the basis of the first verse in Isra' chapter and verses 7 to 18 of Najm chapter in the Quran. There is much discussion concerning the extent and manner in which the Ascension took place. Orientalists have scrutinized issues related to the Ascension of the Prophet of Islam. They have published their research on this matter in the form of articles and books. There are various opinions concerning the Ascension.

Dante Alighieri is among the first orientalists to examine the Ascension of the Prophet of Islam (Munis, 1970). Moreover, at the dawn of the twentieth century, a Spanish orientalist named Miguol-Asin Palacios gathered information about the Ascension from Muslim sources such as Quranic exegeses and traditions from the Prophet of Islam. In his examinations of the Ascension of Prophet Muhammad, Palacios mostly utilized the views of Ibn Arabi (ibid, pp. 1049-1053). This research work utilizes a descriptive-analytical approach and seeks to answer the following questions.

- What are the views of orientalists concerning the Ascension of the Prophet of Islam?

- To what extent are these views acceptable in connection with Islamic teachings?

\section{Terminological Definition of Mi'raj}

In Arabic, mi'raj is something with which one can ascend (Ibn Manzur, 1994; Atabaki, 2001). However, it is terminologically used to refer to the journey of the Prophet of Islam from Mecca to Bayt al-Muqaddas and then on to the heavens as well as his return home. Islamic traditions indicate that such a journey was only made by the Prophet of Islam and only once at that.

After the Ascension, the Prophet of Islam returned directly to Mecca and informed the people of this important event, presenting them with conclusive proof of his ascension. Moreover, throughout his prophethood, he told the people about some of his observations during the Ascension in uncomplicated language. Many such narrations can be found in books of Hadith and exegeses of the Quran (Makarim Shirazi, 1996; Tayyib, 1999; Ibn Kathir Damishqi, 1998; Tha'alibi, 1997). 


\section{Lack of Evidence in the Quran concerning the Ascension}

Micheal Sells, an orientalist, believes that there is no clear indication of the Ascension in the Quran, and therefore, it cannot be believed (Sells, 2001).

The absence of the term mi 'raj in the Quran cannot be stated as a reason that the Ascension did not take place. It merely indicates that the Quran did not utilize this term. In the first verse of chapter Isra' as well as verses 7 to 18 of chapter Najm and verse 45 of chapter Zukhruf in the Quran, the matter of Ascension is described differently. The Quran speaks of the Ascension of the Prophet of Islam in three different manners.

- Verses that directly denote the Ascension but do not explain the matter (i.e. verse 1 of chapter Isra')

- Verses that directly explain aspects of the Ascension of the Prophet of Islam (i.e. chapter Najm, verses 7 to 18)

- Verses that indirectly indicate the Ascension of the Prophet of Islam (i.e. chapter Zukhruf, verse 45)

As seen above, the Ascension of the Prophet of Islam is evidenced in the Quran, and Muslim exegetes have utilized this evidence to expound on the Ascension (Tabataba'i, 1996; Makarim Shirazi, 1996; Qumi, 1989; Bahrani, 1995; Tusi, 1982; Najafi Khumayni, 1978; Thaqafi Tihrani, 1978; Razi, 1988; Surabadi, 2002; Maybudi, 1993; Sayyid ibn Qutb, 1991; Suyuti, 1984; Alusi, 1994; Tabari, 1991; Qumi Mashhadi, 1989).

\section{The Manner of the Ascension}

One of the most important matters related to the Ascension of the Prophet of Islam is whether it really happened or was merely a dream. If it really happened, was it a solely spiritual journey or was the body of Prophet Muhammad also involved? Orientalists answer these questions in different manners.

\section{The Ascension as a Dream}

Constantin Virgil Gheorghiu, Karen Armstrong, and Reynold Alleyne Nicholson are of the opinion that the Ascension of the Prophet of Islam was a dream (Gheorghiu, 1964; Armstrong, 2004). Nicholson describes the Ascension of the Prophet of Islam as follows:_A short time before the emigration of Prophet Muhammad from Mecca to Medina, he saw in a dream that he was taken from the Kaaba to Bayt al-Muqaddas and then was elevated to the seventh heaven (Nicholson, 2001).

The Ascension of the Prophet of Islam was not a dream but rather a waking journey. Describing the Ascension of the Prophet of Islam, the Quran states:

Immaculate is He who carried His servant on a journey by night from the Sacred Mosque to the Farthest Mosque whose environs We have blessed, that We might show him some of Our signs (The Holy Quran 17: 1).

Elsewhere, the Quran states:

Certainly he saw some of the greatest signs of his Lord (The Holy Quran 53: 18).

According to these verses, showing the great signs of creation to the Prophet of Islam was the main purpose of the Ascension (Tusi, 1982; Zamakhshari, 2006; Tabarsi, 1993). This purpose could not have been realized in a dream journey since a dream cannot accomplish such a great objective.

The evidence presented by the Prophet of Islam demonstrates the Ascension was an event that actually occurred. It proves that the Prophet of Islam did not ascend to heaven in a dream. As proof, the Prophet of Islam described the progression of the Quraysh caravan, its goods, and its camels. He also described the structure of Bayt al-Muqaddas (Bahrani, 1995). Thus, how can anyone consider such an event to be a dream?

The context of the Quranic verses concerning the Ascension indicates that this event was a kindness to the Prophet of Islam and expressive of his virtue (The Holy Quran 17: 1). This manner of the Quran is incompatible with the idea that the Ascension was a dream (Tabataba'i, 1996).

According to numerous traditions concerning the Quranic verses of Ascension, the Prophet of Islam informed the people of Mecca about his heavenly journey in the morning. This provoked the denial of opponents and led to doubt among Muslims (Majlisi, 1984). If the Prophet Muhammad had only described the Ascension as a dream, there would have been no reason for the denial of opponents or doubt among Muslims. Only a claim about a true journey to the heavens could induce refutation and uncertainty. A mere dream would not have had such consequences (Maybudi, 1993).

\section{The Ascension as Spiritual}

Marie Rose Saguy, Claude Savary, Annemarie Schimmel, and Virgil Gheorghiu consider the Ascension of the Prophet of Islam to have been spiritual (Saguy, 2007; Savary, 1983; Schimmel, 2004). 
Those who believe that the Ascension of the Prophet of Islam was not physical cite a narration by 'Ayisha, one of the wives of the Prophet. According to this narration, during the Ascension of Prophet Muhammad, his body was laying in the room while he journeyed with his soul (Zamakhshari, 2006; Razi, 1988; Tabari, 1991). This narration cannot be accepted since historians concur that the Ascension occurred prior to the Hijra to Medina, whereas the Prophet of Islam married 'Ayisha after emigration from Mecca to Medina. Accordingly, 'Ayisha is not able to present an accurate testimony concerning whether the Ascension was physical or not (Ibn Hisham, 2009; Halabi, 1989; Diyar Bakri, 2009; Majlisi, 1984). Moreover, there is another narration by 'Ayisha stating that the Ascension of the Prophet of Islam was physical (Suyuti, 1984). Considering the facts that in chapter Isra' the Quran states that God carried His servant (the Prophet of Islam) from Masjid al-Haram to Masjid al-Aqsa and that, like all other humans, the Prophet of Islam has both body and soul, it stands to reason that the Ascension was both physical and spiritual (Tabari, 1991; Tabarsi, 1993; Husayni Shah 'Abd al-'Azimi, 1984; Husayni Hamidani, 1984; Razi, 1988; Najafi Khumayni, 1978; Ibn Sharashub, 1959; Razi, 2000).

\section{The Role of Abu Bakr}

Some orientalists believe that Abu Bakr had a role in the acceptance of the Ascension of the Prophet of Islam by the people. They posit that it was only the testimony of Abu Bakr that won the acceptance of the people of Mecca (Brockelmann, 1968; Savary, 1983).

According to historians, after the Ascension, the Prophet of Islam went to Masjid al-Haram in the company of Abu Talib and the rest of the Bani Hashim tribe. In a gathering of a large number of the people of Mecca, he told of his miraculous journey, the Ascension. However, some people challenged his claim and demanded that he describe things he saw in his journey to Masjid al-Aqsa. The Prophet of Islam stated, "On the way from Mecca to Bayt al-Muqaddas, I encountered a caravan that had lost a camel. At the fore of the caravan, a red camel bolted and threw off its load after I passed. This caravan will enter Mecca today before noon." When those present heard this, they left Mecca to meet the caravan and determine the veracity of Prophet Muhammad's sayings. When they realized that everything the Prophet of Islam had described was true, they accepted his Ascension as fact (Tabarsi, 1993; Saduq, 1997; Kulayni, 1971). This shows that it was the evidence provided by the Prophet of Islam that won the acceptance of the people of Mecca, and it was not only the testimony of Abu Bakr that engendered the acceptance of the people.

\section{Conclusion}

In Quranic exegeses and Islamic traditions, the term mi'raj refers to the journey of the Prophet of Islam from Mecca to Bayt al-Muqaddas and then on to the heavens as well as his return to Mecca. Islamic traditions indicate that such a journey was only made by the Prophet of Islam and only once at that. Some orientalists regard the Ascension as essentially true but have different ideas about the manner in which it occurred. For instance, it is believed that the Ascension of the Prophet of Islam transpired in a dream. Others believe that it was not a physical but spiritual journey. The Quran includes verses that signify the occurrence of the Ascension of the Prophet of Islam. Examination of Quranic verses as well as authentic historical accounts demonstrates that the Ascension of the Prophet of Islam occurred both physically and spiritually.

When, after the Ascension, the Prophet of Islam returned directly to Mecca and informed the people of this important event, presenting conclusive proof of his ascension, the people of Mecca accepted the veracity of the Ascension. Therefore, it was not only the testimony of Abu Bakr that won the acceptance of the people of Mecca concerning the Ascension of the Prophet of Islam.

\section{References}

Alusi, M. (1996). Ruh al-Ma'ani fi Tafsir al-Qur'an al-'Azim wa al-Saba' al-Mathani. Beirut: Dar al-Kutub al-'Ilmiyyah.

Armstrong, K. (2004). Zindigani Payambar Islam (H. Kiyanush, Trans.). Tehran: Intisharat Hikmat.

Atabaki, P. (2001). Farhang Jami “ Karburdi Farzan. Tehran: Nashr wa Pazhuhish Farzan Ruz.

Bahrani, H. (1995). Al-Burhan fi Tafsir al-Qur'an. Tehran: Bunyad Bi'that.

Brockelmann, C. (1968). Tarikh Duwal wa Milal Islami. (J. Hadi, Trans.). Tehran: Bungah Tarjumah wa Nashr Kitab.

Diyar, B., \& Husayn, M. (2009). Tarikh al-Khamis fi Ahwal Anfas Nafis. Beirut: Dar Sadir.

Gheorghiu, \& Constantin, V. (1964). Zindigani Hazrat Muhammad Payambari ki az Nau Bayad Shinakht (S. Mihrdad, Trans.). Tehran: Intisharat Darya. 
Husayni, H., \& Muhammad, H. (1984). Anwar Dirakhshan. Tehran: Kitabfurushi Lutfi.

Husayni, S., \& Husayn, A. (1984). Tafsir Ithna 'Ashari. Tehran: Intisharat Miqat.

Ibn K. D. I. (1998). Tafsir al-Qur'an al- 'Azim. Beirut: Dar al-Kutub al-'Ilmiyyah.

Ibn Manzur, \&Muhammad, ibn M. (1994). Lisan al- 'Arab. Beirut: Dar Sadir.

Ibn Shahrashub, M. ibn 'Ali. (1959). Manaqib Al Abi Talib. Qum: Al-Matba'ah al-'Ilmiyyah.

Kulayni, M. ibn Ya'qub. (1971). Al-Kafi. Qum: Dar al-Kitab.

Majlisi, M. B. (1984). Bihar al-Anwar al-Jami 'ah li-Durar Akhbar al-A'immah al-At-har. Beirut: Mu'assisah al-Wafa'.

Makarem, S. N. (1996). Tafsir Nimunah. Tehran: Dar al-Kutub al-Islamiyyah.

Maybudi, R. A. (1993). Kashfal-Asrar wa 'Uddah al-Abrar. Tehran: Intisharat Amir Kabir.

Munis, H. (1970). Tarikh wa Zamani ki Isra' wa Mi 'raj Payambar Rukh Dadi Ast. Majallah Wahid: The Holy Quran.

Najafi, K., \& Muhammad, J. (1978). Tafsir Asan. Tehran: Intisharat Islamiyyah.

Nicholson, R. A. (2001). Tarikh Adabiyat 'Arab. Tehran: Intisharat Virastar.

Qumi, M., \& Muhammad, M. R. (1989). Kanz al-Daqa'iq wa Bahr al-Ghara'ib. Tehran: Wizarat Farhang wa Irshad Islami.

Qumi, I. (1989). Tafsir al-Qumi. Qum: Dar al-Kitab.

Razi (1988). Rawd al-Janan wa Ruh al-Jinan fi Tafsir al-Qur'an. Mashhad: Bunyad Pazhuhish-hayi Islami Astan Quds Radawi.

Razi, F. (2000). Mafatih al-Ghayb. Beirut: Dar Ihya al-Turath al-'Arabi.

Saduq, M. A. (1997). Amali. Tehran: Al-Maktabah al-Islamiyyah.

Saguy, M. R. (2007). Safar Mu 'jizah Asay Payambar. Tehran: Intisharat Mu'assisah Mutali at Hunar Islami.

Savary, C-É. (1983). Muhammad Sitarah-i ki dar Makkah Dirakhshid. Tehran: Intisharat Farrukhi.

Sayyid, I. (1991). Fi Zilal al-Qur'an. Beirut: Dar al-Shuruq.

Schimmel, A. (2004). Muhammad Rasul Khuda. Tehran: Shirkat Intisharat 'Ilmi wa Farhangi.

Sells, M. (2001). Ascension. Encyclopaedia of the Qurān (Brill).

Surabadi, A. M. (2002). Tafsir Surabadi. Tehran: Farhang Nashr Nau.

Suyuti, J. Al-D. (1984). Al-Dur al-Manthur fi al-Tafasir al-Ma'thur. Qum: Kitabkhanah Ayatullah Mar'ashi Najafi.

Tabari, M. J. (1991). Jami ' al-Bayan 'an Ta'wil Ay al-Qur'an. Beirut: Dar al-Ma'rifah.

Tabarsi, F. H. (1993). Majma ' al-Bayan li- 'Ulum al-Qur'an. Tehran: Intisharat Nasir Khusru.

Tabataba'i, M. H. (1996). Al-Mizan fi Tafsir al-Qur'an. Qum. Daftar Intisharat Islami Jami‘ah Mudarrisin Hawzah 'Ilmiyyah Qum.

Tayyib,. Al-H. (1959). Atyab al-Bayan fi Tafsir al-Qur'an. Tehran: Intisharat Islam.

Tha'alibi, M. (1997). Jawahir al-Hisan fi Tafsir al-Qur'an. Beirut: Dar Ihya' al-Turath al-'Arabi.

Thaqafi ,T. M. (1978). Tafsir Rawan Jawid. Tehran: Intisharat Burhan.

Tusi, M. H. (1982). Al-Tibyan fi Tafsir al-Qur'an. Dar Ihya' al-Turath al-'Arabi.

Zamakhshari, M. (2006). Al-Kashshaf 'an Haqayiq Ghawamid al-Tanzil wa 'Uyun al-Aqawil fi Wujuh al-Ta'wil. Beirut: Dar al-Kitab al-'Arabi.

\section{Copyrights}

Copyright for this article is retained by the author(s), with first publication rights granted to the journal.

This is an open-access article distributed under the terms and conditions of the Creative Commons Attribution license (http://creativecommons.org/licenses/by/3.0/). 